\title{
THE PORTS OF THE STATE OF SANTA CATARINA (BRAZIL): IDENTIFYING THE KEY PROBLEMS FACED BY THE EXPORT INDUSTRY
}

\author{
ROCHA I O*, VIDAL L M**, GUTERRES C $\mathrm{D}^{* * *}$
}

\begin{abstract}
Due to the Brazilian large territory, the network of ports was structured in order to to meet the demands at national and global scales. In southern Brazil, more specifically in the State of Santa Catarina, the ports are an inseparable component of the set of characteristics which allowed the state to become, over the 20th century, one of the most industrialized regions in Brazil. The increase in industrial exports of Santa Catarina, mainly after the 1980s, resulted in a more diversified exporting agenda, which benefited from the existing transport infrastructure: roads, airports, rail ways, and ports. This research aimed at identifying and analyzing the main problems regarding ports infrastructure of the state, which affects the large exporting industries. The research methods used were: a) bibliographic and documents review; b) questionnaire survey and semi-structured interviews with a diversified sample including 40 of the largest exporting companies in Santa Catarina; and c) processing and analysis of the data and information collected. The use of questionnaire survey and semi-structured interviews aimed at: eliciting and characterizing the main problems facing the ports infrastructure in the state and identifying the competitive advantages and disadvantages compared to worldwide market competitors.
\end{abstract}

Key Words: Ports, Main problems, Exportation, State of Santa Catarina (Brazil)

JEL classification numbers: H54, M1, R30

Submission Date: 07/10/2012 Revision Date: 06/12/2012 Acceptance Date: 28/12/2012

* Department of Geography, Santa Catarina State University, Florianópolis, Brazil. isa.rocha@udesc.br

** Department of Geography, Federal University of Santa Catarina, Florianópolis, Brazil. leh2@gmx.net

*** Department of Geography, Santa Catarina State University, Florianópolis, Brazil. guterres.rs@gmail.com 


\section{INTROUCTION}

The Brazilian port system has historically addressed the needs of human settlement and economical exploitation. Due to the Brazilian large territory, the network of ports was structured in order to meet the demands at national and global scales. However, from a local perspective, these ports have also triggered regional socio-economic development. In southern Brazil, more specifically in the State of Santa Catarina, the ports are an inseparable component of the set of characteristics which allowed the state to become, over the 20th century, one of the most industrialized regions in Brazil.

The state of Santa Catarina (located in the south of Brazil, Figure 1) stands out in the Brazilian economy due to its precociousness and dynamism of the industrialization and exports of industrialized products. Until the beginning of the 1970's, the exports from Santa Catarina were predominantly composed by lumber, mostly original from the forests of the plateau, whose flow happened mainly via railroads to the Atlantic ports of São Francisco do Sul and Itajaí, or via the rivers in the countryside of the South American territory (Uruguai River) up to the Prata basin (Argentina). Gradually the industrialized products started to appear on the agenda of the state exports and nowadays the state has an important international industrial insertion, helped by a strategic regional organization of the network of transport infrastructure (sea, land and air).

\section{Figure 1.}

State of Santa Catarina and its location in Brazil and South America.

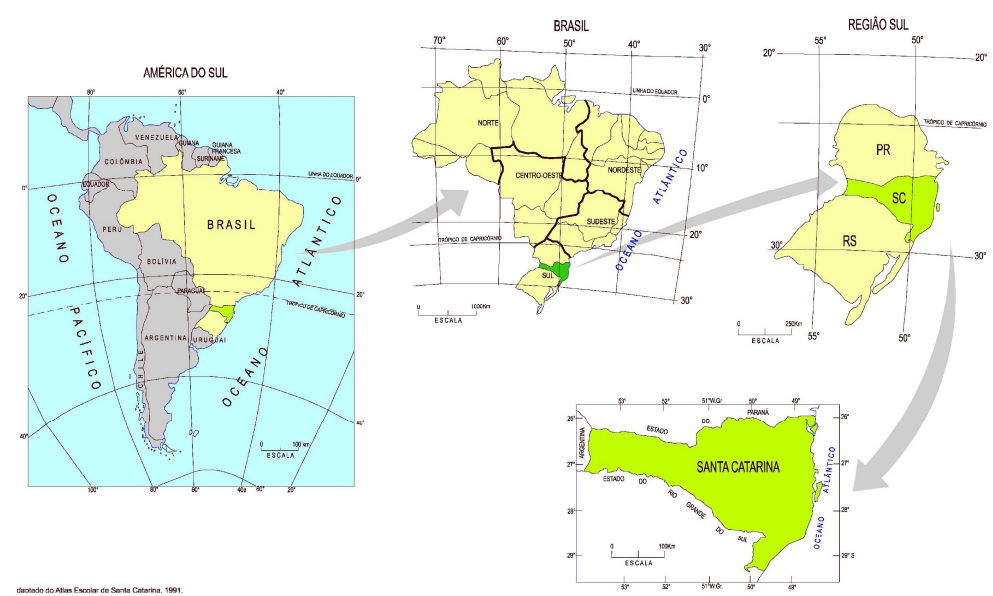

Source: Pedro Agripino Sagaz e Marco Aurélio Leite (SPG/SC, 2012) 
Santa Catarina has a considerable number of ports: Itapoá, São Francisco do Sul, Navegantes, Itajaí, and Imbituba. This is due not only to the physical characteristics of the shore cut through by protected bays and coves (Peluso Júnior, 1952), but also to the existence of a unity on the economic life of its territory marked by the diversity of regional life (Mamigonian, 1966). This diversity is caused by the combination of social factors - with the overlapping of distinct historical moments - and by the natural scene, where the compartmentalization of the relief acted as an important factor in the isolation of the initial centers of settlement. On the Atlantic Slope, the hydrographic bays divide the coastline into compartments of individualized and well established valleys (except for the stretch that begins on the South of Santa Marta's Cape). The rivers that run through the valleys also playe $3 \mathrm{~d}$ an important role in the transportation system, and the main European settlements were located along its route in the XIX century. Among the sea ports, São Francisco, Florianópolis, Imbituba, and Laguna developed on the mouths of the valleys of Itajaí and the Tijucas River, among others. Even acquiring new functions from the XIX century on, because of its dynamic economy brought by the groups of European immigrants and because of the beginning of the national economic development, they already had older port functions related to the moments of the occupation of the settlers from São Vicente (Portuguese origin), the Azorean settlement (Azores Island), and the colonial monopoly of whale fishing, the specific case of Imbituba.

The increase in industrial exports in the state, mainly after the 1980s, resulted in a more diversified exporting agenda, which benefited from the existing transport infrastructure: roads, airports, rail ways, and ports. This research aimed at analyzing the development and current condition of the port network in Santa Catarina; more specifically, it aimed at identifying the main problems facing the ports infrastructure which affect the large exporting industries. The research methods used were: a) bibliographic and document review; b) questionnaire survey and semi-structured interviews with a diversified sample including 40 of the largest exporting companies in Santa Catarina; and c) processing and analysis of the data and information collected. The use of questionnaire survey and semi-structured interviews aimed at: eliciting and characterizing the main problems facing ports infrastructure and identifying the competitive advantages and disadvantages compared to worldwide market competitors.

\section{METODOLOGY}

The main objective of this research was to raise and characterize the main problems faced by the productive sector with regard to transport infrastructure and 
operational costs, and identify the competitive advantage and/or disadvantage regarding competitors worldwide. The questionnaire was applied in a representative sample of different industries located in Santa Catarina (southern Brazil), with companies on the list of the largest exporters (2009) released by the Ministry of Development, Industry and Foreign Trade (MDIC ), as shown below (Table 1):

Table 1.

Large exporting companies surveyed in Santa Catarina (South Brazil) - 2009

\begin{tabular}{|c|c|c|c|}
\hline Companies & $\begin{array}{c}\text { Value of Exports } \\
\text { (U.S. \$ FOB) } \\
2009\end{array}$ & Location (Town) & Products \\
\hline Altona & 31.173 .736 & Blumenau & Metallurgical products \\
\hline Artex/Coteminas & 24.235 .210 & Blumenau & Textiles \\
\hline Artefama & 28.039 .054 & São Bento do Sul & Furniture \\
\hline $\begin{array}{c}\text { Bunge } \\
\text { Alimentos }\end{array}$ & 76.089 .228 & Gaspar & Food (soybean) \\
\hline Busscar & 45.810 .287 & Joinville & Transport Material \\
\hline Eliane & 30.614 .048 & Cocal do Sul & $\begin{array}{c}\text { Non-Metallic Mineral } \\
\text { Products }\end{array}$ \\
\hline Guararapes & 25.815 .518 & Santa Cecília & Wood \\
\hline Irani $\quad$ Móveis & not available & Rio Negrinho & Furniture \\
\hline Metisa & 31.822 .648 & Timbó & Metallurgical products \\
\hline Pamplona & 88.043 .448 & Rio do Sul & Food $\quad$ Products \\
\hline $\begin{array}{c}\text { Perdigão/Brasil } \\
\text { Foods }\end{array}$ & 459.403 .168 & Itajaí & $\begin{array}{c}\text { Food (pig and } \\
\text { chicken) }\end{array}$ \\
\hline Schulz & 21.755 .747 & Joinville & $\begin{array}{l}\text { Metal-mechanical } \\
\text { products }\end{array}$ \\
\hline Seara/Braskarne & 622.625 .67 & Itajaí & $\begin{array}{l}\text { Food (pig and } \\
\text { chicken) }\end{array}$ \\
\hline Terlogs & 75.845 .335 & $\begin{array}{ll}\text { São } & \text { Francisco do } \\
& \text { Sul }\end{array}$ & Food \\
\hline Universal Leaf & 378.904 .548 & Joinville & Tobacco \\
\hline $\begin{array}{c}\text { Vega } \\
\text { ArcelorMittal } \\
\end{array}$ & 32.834 .922 & $\begin{array}{ll}\text { São } & \text { Francisco do } \\
& \text { Sul } \\
\end{array}$ & Steel products \\
\hline Viposa & 22.753 .484 & Caçador & $\begin{array}{c}\text { Skins and Similar } \\
\text { Products }\end{array}$ \\
\hline Vossko & 47.754 .435 & Lages & $\begin{array}{c}\text { Food (pig and } \\
\text { chicken) }\end{array}$ \\
\hline WEG & 518.906 .825 & Jaraguá do Sul & $\begin{array}{c}\text { Electrical and } \\
\text { metal-mechanical } \\
\text { products }\end{array}$ \\
\hline
\end{tabular}

Source: MDIC (2011) 
Together, the companies surveyed represented approximately $40 \%$ of the value of exports from Santa Catarina state (2009). It was not possible to cover a larger universe of research due to the reluctance of many companies to provide data on their exports, which certainly shows the high degree of competition between them in accessing the international market. Nevertheless, our data provide a realistic picture of current logistic infrastructure of exporting companies of Santa Catarina in southern Brazil.

The questions in the questionnaire allowed investigating two different aspects of the logistic export of enterprises. The first concerns the strategies for insertion in the international market, the profile of external customers, related to the situation after the shipment of goods to their destination. The other aspect investigated with regard to logistics for transporting goods from factories to their shipment for export, in most cases by port, or until they leave the state by road, usually in the case of exports to neighboring countries of South America.

\section{RESULTS}

The profile of the companies surveyed differs slightly from the tendency of the State of Santa Catarina as a whole (MDIC, 2011), specifically with regard to countries and economic areas of destination of exports. In this case, the country most often mentioned as a destination was the United States (ten companies), followed by Argentina (nine companies), Germany (eight companies), Uruguay (seven companies) and Canada (six companies). However, we must consider that answers to this item were spontaneous and did not necessarily reflect the values of exports for each country. In relation to the major world regions, the export destination followed approximately the following distribution:

Regarding results related to contracts with overseas customers, most companies adopt international trade agreements like FOB (Free on Board), in which the buyer is responsible for shipping costs and insurance on the time of shipment. However, this option varies greatly according to the logistic facilities that each company has overseas. Some, like WEG, for example, exporting directly to its own subsidiaries in other countries, uses other forms of contracts. The same happens with Vega ArcelorMittal, a subsidiary company of a large multinational group.

The most common types of facilities that companies have in overseas sales offices are present in most of the companies surveyed. Smaller companies, however, instead of maintaining its own structure, outsource service sales representatives. Then, there are storage and distribution centers, especially in the United States and Western Europe, 
the largest markets outside the South American continent, as we have seen.

Companies whose ramifications in other countries include manufacturing facilities are divided into two types: domestic companies globally competitive -they opted to buy or install industries closer to their markets ${ }^{-}$and companies controlled by foreign capital, originally national or not. The units in Santa Catarina are actually affiliates. The example of the first type is WEG, which currently has plants in Argentina (2), Mexico, China, Portugal and India. The only other company surveyed having factories outside Brazil was Busscar, with plants in Colombia and Mexico. Some exports of these companies are even toward their own subsidiaries, as part of their logistic strategy.

On the other hand, exporting companies of Santa Catarina controlled by foreign capital are within the universe surveyed in 2009, Seara (Marfrig Group), Vega do Sul (conglomerate ArcelorMittal), Universal Leaf Tobacco (Universal Corporation), Bunge Foods Vossko and Brazil, the German subsidiary of the corporation of the same name in the food sector. Besides these companies, Terlogs, which manages part of the complex bulk of the port of Sao Francisco do Sul, has strong participation of Japanese capital linked to imports of soybeans; the was reported in the interview that we made to the commercial manager of the terminal. Of all these companies, Vossko was the only one affirming that they have "plants abroad". It may be assumed that these companies also hold a significant portion of their international trade operations between headquarters and branches, although this has not been verified in the verbatim responses to the survey.

Regarding the profile of overseas customers, the answers were very diverse. The most frequent response, however, was "industry", a constant option especially among the largest exporters surveyed, as Perdigão, Seara, and Pamplona, which have meat processing industries with a significant proportion of customers, and WEG, whose major clients are equipment manufacturers that use their electric motors and automation systems. Other industries have companies that are clients of Altona, Artex, Vega, Bunge, and Viposa Vossko. Universal Leaf Tobacco also exports to processing industries whose location they preferred to keep secret. Besides the option "industry", wholesalers appear as guests in a significant portion of the responses. Only one of the companies surveyed said to be exclusively exporting for retail sales, since it is precisely the smaller of the universe surveyed, the Mobile Irani division.

In this panoramic sketch of the profile of companies exporting abroad, the study sought, as mentioned, to better understand the logistics of export business before the board, and its relation to the transport infrastructure in the South of Brazil.

As expected, road transportation is the most widely used, consisting of almost all the freight to the ports, besides being the means by which products are exported to 
Mercosul countries, like Chile and Bolivia (shipping is used in exports to Venezuela and Colombia and other Andean countries). An exception was WEG, who said to send a small portion of its production exported to Bolivia via railroad. On the other hand, the low participation of railways in transport was in more than one case pointed to system failures, which is currently operated by America Latina Logistica company (ALL). The problems reported were the delay of trains and lack of care in handling the goods. However, the viability of railroad transport depends greatly on the nature of the load. In the case of soybeans, which reaches up to twenty days to get stored in the warehouses of the Port of São Francisco do Sul, the railway network in question also covers important areas producing soybean in Brazil, trains becomes the most frequent transport of grain, which in times of crop about 200 cars arrive daily.

In fact, the railroad is the key link in the logistics chain of soybeans exported through the ports of southern Brazil. This does not mean that the railroads did not compete significantly to transport the grain to San Francisco do Sul, since the railway infrastructure would not be sufficient to meet all the demand generated during the harvest.

The alternative of exports by air takes place sporadically, as a last option for the fulfillment of contracts in exceptional circumstances, given the high cost of such freight. For this reason, this is usually associated with modal goods with high added value.

Regarding the analysis of the effect of infrastructure on transport in Santa Catarina export activities, one of the key objectives of this research, two factors emerge as critical: the time elapsed since the product leaves the factory to arrival at the port, and the portion of the final cost represented by the transport within the state.

In no case the transport time elapsed between dispatch of the goods and their arrival was more than one day, confirming the initial hypothesis that the density of transport network in the producing regions of Santa Catarina, and the existence of more than one alternative port, configure considerable advantages for the economic dynamics of the state.

The final portion of the cost represented by the transport for exports was considered more difficult to obtain, because many companies surveyed preferred to keep this issue secret. Information obtained is summarized below:

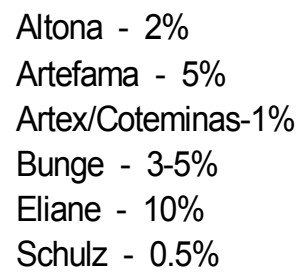




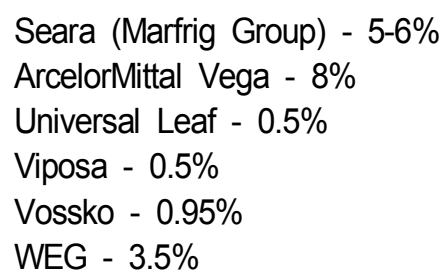

Obviously, costs (price per unit weight) are an important variable that should be taken into account before these data. Other important information was obtained: the cost of transportation within Brazil (Santa Catarina) is very low compared to the final value of the exported product, and even very low compared to ocean freight. This means that the infrastructure of transport can hardly be a factor that made exports difficult and, in fact, it was not considered at any time in the responses of companies as a major problem faced. This is because, as it was found, the weight of these logistic operations is much less relevant to business than imagined. Thus, as an initial working hypothesis, which was to detect problems for exports in the transport network, we saw quite refuted by the facts, at least judging by the opinions of professionals. It is worth remembering that in most of the studied cases transport is outsourced. Thus, the problems will probably end up affecting the road transport enterprises more directly.

Another important issue raised refers to recurrent natural disasters. Due to its geographical position, Santa Catarina is constantly affected by diverse climate events such as: heavy rains leading to floods, droughts, tornados, etc. The ports of Itajai and Navegantes are placed at the mouth of the Itajaí-Acu River and are the most affected ports due to recurrent severe flooding. These floods are common on this Atlantic river basin, mainly during the periods when the climate phenomenon called El Niño occurs.

A period of heavy rains for over three months in 2008 affected the territory of the state and resulted in intense flooding. As a consequence the level of the Itajaí-Acu River went up to 11.5 meters above normal and various catastrophic landslides were registered, mostly in areas close to the mouth of the river, in the medium and low valley zones. This episode affected around 2 million people living in 60 different towns. During the flood peaks, the port of Itajaí had a good amount of its docking berths destroyed due to the powerful river stream. As a consequence, the port activity stopped for over three months. The complete restoring of the damages were only concluded in 2011, causing great difficulties for foreign commerce in the state. The port of Itajai has tradition in the exportation of frozen pig and chicken to the world market.

The recovery of the port was due to a quick response and financial support from President Lula's government. The docking berths were restored and the Itajaí-Açu River 
channel was dredged. The dredging used a US\$ 30 million budget and came from the National Program for Dredging, which is part of the Federal Government's National Economical Growth Speeding Program (PAC). In the first semester of 2011, the Port of Itajaí had an output of 1.849.662 TEUS, a growth of $57 \%$ if compared to the 789.983 TEUS which were operated in the same period in 2009. However, even with the restoring completed, this volume of activity is still lower than the 3.182.915 TEUS which were operated in 2008 during the first semester, before the damage cause by the giant flood.

\section{CONCLUSIONS}

At present it is very important for the port sector administration costs, efficiency, service accessibility, and reliability in transport. To perform these actions ports must be submitted to the innovation process or organizational changes ( Lee and Song, 2008).

The interviews showed that the largest export logistic problems faced by large exporting companies in the South of Brazil are: a) the disadvantage given by an overvalued exchange rate of the Brazilian currency; b) the need for modernization of ports infrastructure, both in operational and administrative terms; and c) and excessive bureaucracy existing in different governmental bodies related to exports. Some sporadic complaints should also be mentioned, such as the high cost of ocean freight and the monopolistic practices of big shipping companies.

The exchange rate policy of overvaluation of the Brazilian currency (R\$) is a long-standing problem, which affects differently to all exporting industries. Not surprisingly, this claim was further emphasized by furniture companies, historically one of the most affected. One reason for the fragility of this sector is that its inputs are all of national origin, pushing up production factors with respect to exports performed in U.S. dollars.

Companies that import a larger quantity of inputs in U.S. dollars end up, thus offsetting the disadvantage exchange occurred at the time of export. With varying degrees of vulnerability, however, all businesses suffer the consequences of current economic policy of maintaining overvalued currency. It is considerably symptomatic, indeed, that this complaint has appeared with greater insistence in the questionnaires during the second half of 2009, when the speculative movement around the strengthening of the Brazilian currency crisis at the end of the financial markets then rose the value of Brazilian currency on the dollar even more.

However, the problem most reported in the questionnaires was the need for modernization of ports infrastructure in different instances: a) the need to create more 
back area for containers; b) need to increase the depth and length of the berths to fit them to the evolution of naval engineering, which enables the construction of cargo ships of increasingly larger sizes; and c) modernization of port management in public ports, especially in the face of private competition in the state represented by private port (São Francisco do Sul, for example, operates in government office hours).

As seen, most of these problems requires costly engineering works and are difficult to solve, even in view of the location of the ports in densely populated urban centers (Itajai), or in areas of high environmental vulnerability (San Francisco do Sul and Imbituba); in addition to the rains in November 2008 damaging a considerable part of the structure of the most important port, Itajai.

Among business people with whom we had contact, is also common to observe the criticism to well-articulated and rigid labor organization of freelance stowage workers, qualified as an "extra cost" in port operations due to better working conditions and remuneration earned by them, during years of labor struggles. Such comments are invariably accompanied by praising the work regime existing in some other ports and private terminals, where dock workers do not enjoy the status of autonomous, work longer hours and are underpaid. However, despite its persistence in the discourse of business, it is clear that the "additional cost" represented by unions of longshoremen, checkers, etc., (where they still exist) is incomparably smaller than the serious shortcomings mentioned before.

Finally, another major obstacle to exports recorded in the questionnaire responses is called "excessive bureaucracy" of the competent governmental bodies, companies assigned to different instances, especially in the port of Itajai. The slowness of the Internal Revenue Service was the main problem mentioned, in view of procedures considered antiquated by enterprises and the amount of goods that lose the time of shipping and fall into the "red channel" of surveillance, or even reported cases of deliberate delays and abuse power by taxes. These delays lead to considerable losses, because companies have to bear the maintenance costs of the goods at the port until its complete clearance, and also when this happens, they have to wait for the opportunity of a new shipment to the destination previously programmed, not to mention damage to their image regarding customers abroad that may cause delays in delivery. Reportedly, for goods with low added value and costs generated by the "red channel", the IRS may charge to the profit margin that would be obtained under normal conditions of sale. In the case of the food industry, complaints refer to the structure of supervision of the Ministry of Agriculture, which is regarded as "archaic", "obsolete" and "corrupt" by some interviewees.

Obviously, it is necessary to look closely at the origin of these complaints, coming from their own companies interested in boosting their exports to the fullest. 
There is clear imbalance between the export potential of companies surveyed and the operational capacity of the state. Policies and institutional governmental structures (taxes, fiscal controls, exchange, etc.) need to be performed with due rigor. Still, it is clear that such actions may be effected without impairing the competitiveness of Brazilian exports of manufactured products, which have faced the new changes of the world market with the rapid rise of economic empowerment of East Asia (Lee and Cheong, 2011), especially China.

Some of the results presented here were published in Rocha et al. (2011). This article is part of the research carried out with funds from the Edital $\mathrm{MCT} / \mathrm{CNPq}$ $15 / 2007$. 


\section{REFERENCES}

Conorath, G. D. and Rocha I. O. (2011) "Análise sócio-espacial de São Francisco do Sul-SC/ Brasil", in Annals XIII EGAL - Encuentro de Geógrafos de América Latina: Estableciendo puentes en la geografia de Latinoamérica, Universidad Nacional, San José-Heredia, Costa Rica, 1-10

Lee, E.-S. and Song D.-W. (2008) "Lean organization: a new direction for ports in global

Logistics", Journal of International Logistics and Trade, vol 6, n. 1, pp. 75-91

Lee, M. I. and Cheong, I. (2011) "A Critical Review on Regional Integration Processes in East Asia", Journal of International Logistics and Trade, vol 9, n. 2, pp.33-55

Mamigonian, A. (1966) "Vida Regional em Santa Catarina", Orientação, IGEO/USP, São Paulo, vol 2, 35-39

Mamigonian, A. ( 2005) "Estudos de geografia econômica e de história do pensamento geográfico", Universidade de São Paulo, Tese [Livre Docência]

MDIC, 2011. Ministério do Desenvolvimento, Indústria e Comércio Exterior. http://www.mdic.gov.br (accessed November 12, 2011).

Peluso Jr. V. A. (1952) "O relevo do Estado de Santa Catarina", in Publicação, Departamento Estadual de Geografia e Cartografia, Florianópolis, vol 3(1),1-56

Rangel, I. (2005) Obras Reunidas, Rio de Janeiro: Contraponto, vol 2, 409-551

Rocha, I.O.,Vidal, L.M., Ferreira, L.S. (2010) "Analysis of Santa Catarina's port infrastructure during the XXth century", in Annals 12th World Conference on Transport Research 2010 - 12th WCTR 2010, 2010, Lisbon, 1-13

Rocha, I. O. (2011) "Exportações industriais de Santa Catarina (1950-2010)" in Armen Mamigonian. (Org.). Santa Catarina: estudos de geografia econômica e social, Livros Geográficos, Florianópolis: Departamento de Geociências/Centro de Filosofia e Ciências Humanas/UFSC, 1 (IV), 249-328

Rocha, I. O., Vidal, L.M., Guterres, C. D. (2011) Análise da infra-estrutrura logística das indústrias exportadoras de grande porte de Santa Catarina, in Revista Brasileira de Gestão e Desenvolvimento Regional, vol 7, 52-75

SPG/SC (2012). Secretaria de Estado do Planejamento de Santa Catarina.

http://www.spg.sc.gov.br (accessed January 30, 2012) 